\title{
GOD, SCIENCE, AND METHODOLOGICAL NATURALISM
}

\author{
Ian Anthony B. DAVATOS, \\ Palawan State University \\ PHILIPPINES \\ Email: iadavatos@psu.palawan.edu.ph
}

\begin{abstract}
In this paper, I call into question a commonly assumed principle in science known as methodological naturalism, which is the idea that science should only accept natural, as opposed to supernatural, explanations. In support of $M N$, two arguments are commonly thrown against the idea of theistic explanation in science: the science stopper argument and the God-of-the-gaps argument. The science stopper argument states that appealing to theistic explanations hinders science from making steady progress; it simply stops science from its tracks. In other words, abandoning MN spells the death of science. The God-of-the-gaps argument states that appealing to God when explaining phenomenon is a form of an argument from ignorance, what critics call God-of-the-gaps thinking, which is considered to be fallacious reasoning. Any gap in nature that is explained by God, so the argument goes, is simply an appeal to our ignorance that we have no yet found the correct explanation to such natural mystery. In this scenario, an appeal to God is assumed to simply show our lack of knowledge with regard to the workings of nature. After introducing these arguments, I assess their strength by looking at the history of methodological naturalism. I then show how the history of science does not only fail to support these arguments but actually refutes them.
\end{abstract}

Keywords: methodological naturalism; God of the gaps; history of science; intelligent design theory; science stopper; scientific explanation;

\section{INTRODUCTION}

In this paper, I call into question a commonly assumed principle in science known as methodological naturalism (MN), which is the idea that science should only accept natural, as opposed to supernatural, explanations. In support of $\mathrm{MN}$, two arguments are commonly thrown against the idea of theistic explanation in science: the science stopper argument and the God-of-the-gaps argument. The science stopper argument states that appealing to theistic explanations hinders science from making steady progress; it simply stops science from its tracks. In other words, abandoning MN spells the death of science. The God-of-the-gaps argument states that appealing to God when explaining phenomenon is a form of an argument from ignorance, what critics call God-of-the-gaps thinking, which is considered to be fallacious reasoning. Any gap in nature that is explained by God, so the argument goes, is simply an appeal to our ignorance that we have no yet found the correct explanation to such natural mystery. In this scenario, an appeal to God is assumed to simply show our lack of knowledge with regard to the workings of nature. In order to avoid the problematic God-ofthe-gaps, what is needed is a persistence to look for naturalistic explanations even if one is currently unable to find anything like it. Thus, according to this argument $\mathrm{MN}$ is a tool that encourages scientific persistence, as opposed to scientific laziness. As Robert Pennock states,

"By disqualifying short-cuts, the naturalist principle also has the virtue of spurring deeper investigation. If one were to find some phenomenon that appeared inexplicable according to some current theory one might be tempted to attribute it to the direct 
intervention of God, but MN prods one to look further for a natural explanation."1 These two arguments are historical arguments against supernatural causation or at least arguments that rely heavily on historical facts to make their case. For that reason, it is necessary to take a tour in history to see whether these arguments have any bite. In what follows, I shall discuss a short history of science in relation to $\mathrm{MN}$, starting from the ancient Greeks down to the theory of evolution. It is of course not possible to make a comprehensive historical treatment of $\mathrm{MN}$ and I do not claim to provide one. One of my main objectives is to show that there are facts in the history of science that either refute or at least undermine the premises of the two arguments mentioned above. If it were shown that there is even one historical example of an appeal to supernatural that provided some impetus for further scientific inquiry rather than completely derailed it, then the science stopper argument would have been a failure all along. Likewise, if there is an appeal to God that either does not commit the fallacious appeal to ignorance or does not encourage scientific laziness, then the God-of-the-gaps charge is confused. In the coming sections, I shall argue that when one looks at the historical facts, one will see that both these arguments are historically flawed.

But aside from undermining two arguments for $\mathrm{MN}$, there are also other reasons why the discussion of the history of MN is essential for our purposes. Firstly, it will show that MN has not always been a hallmark of science, since there have been scientists - such as Aristotle and William Paley-who did science without presupposing MN. In fact, the revival of the design theory in science, currently exemplified by the so-called Intelligent Design theory ${ }^{2}$, suggests that MN may not be an essential part of what makes science what it is. Secondly, the motivations for adopting MN have been multifaceted historically speaking. While there are purely secular reasons for some scientists to adopt $\mathrm{MN}$, we will see that the pioneers of modern science adopted MN with the Christian framework in mind.

One implication of this is that the understanding of $\mathrm{MN}$ as the working assumption that there is no God is historically inaccurate. Also, the differing motivations suggest that a defense or a critique of MN should not rely on the motivations of its defenders or opponents, but on the merits of each argument. Thirdly, the focus of this survey is to illustrate the presence or absence of MN in the different scientists throughout history. Many of these scientists are considered theistic scientists as theism is defined here but some are not theists. Because of this narrow focus, I do not include the materialists of antiquity who conceived of God as a body because such a view is basically pantheistic, and pantheism is not part of the scope of this study. Lastly, it will be clear in the discussion that there is a correlation between the widespread turn to MN during the rise of early modern science and the growing suspicion to, or even dismissal of miracle claims. This correlation highly suggests that there really is a clear tension between the commitment to $\mathrm{MN}$ and the commitment to theism, and the only plausible solution is to abandon one commitment for the other. And so, to the history of $\mathrm{MN}$, we now turn.

\footnotetext{
${ }^{1}$ Robert Pennock, Tower of Babel: The Evidence against the New Creationism, 196.

${ }^{2}$ Some of the representative works of this theory are the following: Michael Behe, Darwin's Black Box: The Biochemical Challenge to Evolution (New York: Free Press, 1996); Stephen C. Meyer, Darwin's Doubt: The Explosive Origin of Animal Life and the Case for Intelligent Design (San Francisco: HarperOne, 2013); Stephen C Meyer, Signature in the Cell: DNA and the Evidence for Intelligent Design (New York: HarperCollins Publishers, Inc., 2009); William Dembski, The Design Inference: Eliminating Chance through Small Probabilities (New York: Cambridge University Press, 1998); Douglas Axe, Undeniable: How Biology Confirms Our Intuition that Life is Designed (New York: HarperOne, 2016); Jonathan Wells, The Myth of Junk DNA (Seattle: Discovery Institute Press, 2011). With the exception of Stephen Meyer (who is a philosopher of science), all authors mentioned here are scientists.
} 


\section{A SHORT HISTORY OF METHODOLOGICAL NATURALISM}

At first glance, it would seem a tautology to affirm $\mathrm{MN}$ as a presupposition in science. In fact, when we go back to ancient Greece, we find the view of ancient Greek thinkers attributing natural causes to such phenomena as earthquakes and lightning instead of opting for the popular view that these phenomena are caused by the whims and emotions of the gods. What stood out in the thoughts of Presocratic philosophers such as Thales $(620 \mathrm{BC}-$ $546 \mathrm{BC}$ ) is their desire to find purely natural explanations to natural phenomena. ${ }^{3}$ Another ancient thinker, the Roman philosopher Seneca (4 BC - 65 AD), is known to have calmed his fellow citizens who have been fearful of astronomical events believed to be caused by angry deities. Suspicious of appeals to supernatural agency, Seneca remarked, "These phenomena have causes of their own."

What these examples purport to show is that the idea of $\mathrm{MN}$ is already present in the minds of ancient Greek thinkers although the term itself and the vigorous debates over it are fairly recent. When we reach Aristotle however, the picture is not so clear. Although mostly known as a philosopher, Aristotle $(384-322$ BC) is also considered to be an early scientist whose natural science enjoyed recognition well until the seventeenth century. He explains certain things in nature by appealing to four causes: material, formal, efficient, and final. The final cause for Aristotle is God whom he called among others "a mover which moves without being moved"4 or to put it simply, the unmoved mover. The natural question that arises is: is Aristotle's explanation of change in nature naturalistic or supernaturalistic? We must exercise care in answering this since it might turn out that the question is invalid by being anachronistic. Our question presupposes that there is a distinction between naturalistic and supernaturalistic explanation but Aristotle does not see the world divided into this dichotomy. In fact, calling his explanation as largely naturalistic or somehow supernaturalistic seems misconceived: he operates within a set of assumptions among which is the idea that God is not something opposed to or separate from the natural but is rather an essential component for its very constitution. ${ }^{5}$ In fact for Aristotle, God is the source of the regularity in nature and what makes the scientific study of nature difficult is not the postulation of God but the reality of chance. ${ }^{6}$ In the case of Aristotle at least, it is clear that the idea of God is not supposed to be disruptive of scientific inquiry (a science-stopper in common parlance) but is actually the sort of entity that makes scientific inquiry possible by enabling him to postulate that nature will be lawlike and regular.

So is Aristotle a methodological naturalist? If $\mathrm{MN}$ is understood as the view that science should never appeal to supernatural entities, such as God, it is of course clear that he is not. Characterizing God as the Unmoved Mover might suggest that Aristotle takes God to be natural whose ontological status is just like all the other substances in the world but this is actually far from the case. Aristotle described God as "a living being, most good, so that life and duration continuous and eternal belong to God; for this is God."7 This passage makes it clear that the God of Aristotle resembles closely the God of theism. However, Aristotle's God did not create the cosmos because the cosmos is also "continuous and eternal" like God. By this, it is clear that Aristotle does not subscribe to methodological naturalism. To remove

\footnotetext{
${ }^{3}$ For a survey, see G. S. Kirk \& J. E. Raven, The Presocratic Philosophers (Cambridge: Cambridge University Press, 1957).

${ }^{4}$ Aristotle, Metaphysics, 1072a20-25. I utilize the Bekker numbering system for Aristotle in this work.

${ }^{5}$ Aristotle, Metaphysics, $1072 \mathrm{a} 26$.

${ }^{6}$ Aristotle, Physics, 197a31-35.

${ }^{7}$ Aristotle, Metaphysics, A. 7. $1072 \mathrm{~b} 25$.
} 
God from Aristotle's picture of the universe, as the methodological naturalist might suggest, is to do Aristotle a grave injustice. Since God plays an indispensable role within Aristotle's theory of motion, we may characterize Aristotle's approach as methodological theism, the idea that God as conceived by generic theism can play a role in any scientific theory.

Looking at the big picture, we notice that presocratic thinkers already subscribe to some form of MN, albeit implicitly. This is however contrasted in the case of Aristotle who is clearly not a methodological naturalist but some sort of methodological theist. And so, it would be rash to claim that $\mathrm{MN}$ is already immanent in ancient Greek thinking. Meanwhile, it is interesting to note that science as we know it today did not develop in ancient Greek culture. Why is this so? The answer lies in examining how the ancient Greeks view the universe. One influential idea from the Greeks is the notion that the celestial realm is "of a qualitatively different order of being (divine, infinite, perfect) than that of the terrestrial (mundane, finite, imperfect, changeable)." 8 These two conceptions led to different treatments of these realms. A study of the celestial realm, including the divine, primarily involves an exercise in reason: since as the ancient Greeks believe, nature "and even the gods themselves - were subject to, and had to work within or around, the boundaries imposed by this eternal, rigid, ultimate order of reality." "What is needed to understand nature is the discovery of rational principles that govern this order of reality. This discovery can be achieved primarily through the use of reason alone. Del Ratzsch remarked:

While Aristotle believed that investigation had to rest on observation he believed that such observation need not be extensive and need not involve elaborate experimentation. According to Aristotle, we had an inductive mental faculty which from just a few bits of observational data could extract the general rational patterns embedded in the observed reality in question. Thus, extensive observation was not necessary. And Aristotle saw experimentation as potentially distorting nature. But if nature in experimental circumstances were distorted or coerced into doing things it otherwise would not do, then the results of any such experimentation obviously would not reveal any basic truths about real nature itself. ${ }^{10}$

The influence of the ancient Greek worldview is felt even in the formulation of early Christian thought, as manifested in Augustine's use of Plato and Aquinas' use of Aristotle in their respective attempts to integrate Greek philosophy into the Christian worldview. However, early Christian thinkers saw certain fundamental differences between the ancient Greek worldview, which simply means the worldview of the ancient Greeks which culminated in Aristotle, and biblical revelation. As has been said, the Aristotelian worldview believes that the world is eternal. However, biblical revelation claims that God created the world ex nihilo, out of nothing. The existence of the world is therefore contingent so that only God is eternal. And since the world is created out of nothing, it means that there is no preexisting material from which it is made. Moreover, since only God is eternal, there are no absolute principles that necessarily constrain how God will create the world; the creation of the world is completely determined by God's will and free decisions. And since the world is created according to God's own free will, it follows that we cannot know the nature of the world through the use of pure reason alone so that there is a need for sustained and rigorous observation and examination. It is largely within the backdrop of this Christian doctrine of

\footnotetext{
${ }^{8}$ Robert C. Bishop, "God and Methodological Naturalism in the Scientific Revolution and Beyond,"

Perspectives on Science and Christian Faith 65, no. 1 (March 2013): 10-11.

${ }^{9}$ Del Ratzsch. "The Religious Roots of Science," in Science and Religion in Dialogue, ed. Melville Y. Stewart

(Chichester: Wiley-Blackwell, 2010), 56.

${ }^{10}$ Ibid., 56. Emphasis in the original.
} 
creation that early modern scientists carry on their scientific explorations. Even authors sympathetic to MN, such as Ronald L. Numbers, agrees about this historical fact. Numbers rightly pointed out that "belief in natural causes and the regularity of nature antedated the appearance of Christianity."11 But Christianity encouraged the search for natural explanations in nature. Long before the birth of modern science and the appearance of "scientists" in the nineteenth century, the study of nature in the West was carried out primarily by Christian scholars known as natural philosophers, who typically expressed a preference for natural explanations over divine mysteries. ${ }^{12}$

It might seem ironic but the facts reveal one important thing: Christianity encouraged the practice of science that invokes natural explanations rather than appeal to divine mysteries. At first glance, this might suggest that Christianity even in its early stages is in explicit support for MN but the data is not so clear. There are good reasons to refrain from making any hasty conclusions. Take for instance the case of John Philoponus (490-570 AD), a Christian philosopher during late antiquity. He argued against Aristotelian science, more specifically Aristotelian dynamics, and tried to replace it with a scientific theory akin to our modern theory of inertia. His religious commitments led him to believe that the world is created by the Christian God, which consequently entailed that the cosmos and everything in it is not divine in contrast to the claim of the then reigning Aristotelian worldview. Moreover, this belief in God's creation led Philoponus to the idea that the heavens and earth share the same properties and principles of motion, a view that might appear commonsensical now but is actually revolutionary during Philoponus' time.

This turn of events from the reigning worldview to an increasingly naturalistic approach is significant in the discussion of MN. We already see how integrated theism is in Aristotelian science but its influence starts to disintegrate to be replaced by a more naturalistic approach in doing science. But in the case of Philoponus, what prompted him towards such naturalistic approach is his very religious commitment. He is motivated by a specific religious orientation, more specifically by the belief that there is a vast qualitative difference between God's creation (universe) and God Himself. More so, he also came to believe, pace Aristotle, that all of God's creation, both the celestial bodies and earthly ones, are united in their material constitution. At this point, it will soon be clear how significant the distinctions are between the different forms of $\mathrm{MN}$ so that we need to thread a thin line to answer whether Philoponus is a methodological naturalist. We have to ask a more specific question: what form of $\mathrm{MN}$ are we talking about?

It seems clear that Philoponus is a methodological naturalist. His intellectual break from Aristotelian science that is infused in divine agency resembles a vivid transition from a form of science tied to some sort of theism towards a science that is in practice naturalistic. But in terms of the other form, the issue becomes blurry. Does Philoponus' science preclude the idea of the supernatural? This seems unlikely since it is his particular idea of God and how God is related to His creation that serves as springboard towards his practice of science that is naturalistic. The role that God plays in Philoponus' thinking is within the higher-order level of explanation: it serves as the basis for the assumption that the created world can be understood on its own apart from one's knowledge of its Creator. This higher-order assumption consequently undergirds Philoponus' practice of science that is naturalistic.

\footnotetext{
${ }^{11}$ Ronald L. Numbers. "Science without God: Natural Laws and Christian Beliefs," in When Science and Christianity Meet, ed. David C. Lindberg and Ronald L. Numbers (Chicago: The University of Chicago Press, 2003), 266.

12 Ibid.
} 
When seen in the context of how pervasive Aristotelian science is during Philoponus' time, we start to realize how crucial and important this religious assumption is to Philoponus in bringing about science that appeals to purely natural, as opposed to supernatural, explanations. Indeed, much hinges on what is meant by doing science as if metaphysical naturalism is true. Does this mean that all religious assumptions are disbarred from scientific practice in all context? If that is the case, Philoponus would not be a methodological naturalist because his religious assumption is pivotal to how his practice of science turned out. Without his particular theistic framework, it is unlikely that Philoponus would have reached the scientific conclusions that he did. In sum, we have a case in which a scientist upholds the idea that science should resort only to natural (as opposed to supernatural) explanations while affirming that God and His transcendent relation to the world is what made the former assumption possible.

When we reach the early modern era, the hold of Christian theistic assumptions in science remain vigorously present but like in the case of Philoponus, Aristotle's particular view of God and the universe barely holds. It was Rene Descartes (1596-1650) who explicitly endorsed the idea that natural philosophy (the term at that time for what we might currently call science) should start dispensing final causes and focus its study on efficient causes. ${ }^{13}$ We have learned that for Aristotle God is the final cause of all movements in the cosmos. In contrast, for Descartes God's role in the explanation of motion is to be an immediate efficient cause. ${ }^{14}$ Descartes further believes that God is immutable and this property of divine immutability is what guaranteed that the laws of nature would also be immutable. Similar to Aristotle, Descartes' view of God guarantees the regularity and lawfulness of nature. Although they disagree on the details of their theological beliefs, Descartes resembles more the stance of Aristotle than the stance of Philoponus in connection to MN. In a nutshell, Descartes is no friend of the methodological naturalist.

The transition from Descartes' practice of science to the theologically laden practice of early modern scientists should by now not be surprising. Indeed, the rise of modern science is indebted to a lot of philosophical commitments whose roots can be traced to Christian theism itself. Philosopher of science Del Ratzsch has detailed how the emergence of modern science, spearheaded by such thinkers as Nicholas Copernicus (1473-1543), Robert Boyle (1627-1691), Johannes Kepler (1571-1630), Galileo (1564-1642), and Isaac Newton (1642-1727) among others, is rooted in "a basic doctrine of Christian theology - the doctrine of creation," 15 among others. Newton, for instance, states that "the motions which the planets now have could not spring from any natural cause alone, but were impressed by an intelligent agent." 16 There is no question that by intelligent agent, Newton means God. Consequently for Newton, there is no nature acting by itself or possessing its own powers. As Samuel Clarke remarked, "The course of nature, truly and properly speaking, is nothing else but the will of God producing certain effects in a continued, regular, constant, and uniform manner." 17

\footnotetext{
${ }^{13}$ Peter Harrison, "Naturalism and the Success of Science," Religious Studies 56, no. 2 (2018): 8.

${ }^{14}$ Rene Descartes, The Philosophical Writings of Descartes, ed. John Cottingham and Robert Stoothoff, trans. Dugald Murdoch (Cambridge: Cambridge University Press), 1:202.

${ }^{15}$ Del Ratzsch, "The Religious Roots of Science," in Science and Religion in Dialogue, ed. Melville Y. Stewart, (Chichester: Wiley-Blackwell, 2010), 57.

${ }^{16}$ Isaac Newton, Isaac Newton's Papers and Letters on Natural Philosophy, ed. I. Bernard Cohen (Cambridge: Harvard University Press, 1958), 284.

${ }^{17}$ Samuel Clarke, The Works of Samuel Clarke, D.D., $1^{\text {st }}$ vol. (London: 1738), 697.
} 
Indeed in these early years of modern science, scientists did not see their discipline as something opposed to or even separate from their faith; rather, they see science as revealing the complexity and beauty of the universe, which they view as a reflection of God's beauty, power and majesty. There is however one thing that is becoming clear: as Robert C. Bishop surveyed, it is the idea that "to understand creation requires taking the nature of created things on its own terms." 18 This is most apparent in the case of Galileo who is known for his two books metaphor, the idea that creation and the Bible are two different books that both originated in God. Galileo remarked that the book of nature, i.e., creation, is written in the language of mathematics and can be understood apart from direct divine revelation. Johannes Kepler followed this train of thought by noting that the role of astronomers is to be priests discovering and making sense of God's book of nature. ${ }^{19}$ This differentiation between God's two books is pivotal to the intellectual turn of early modern scientists towards MN, which according to Bishop is "what guided natural philosophers in their study of created natures, on their own terms, to understand them as accurately as possible. ${ }^{, 20}$ But interestingly, the MN exhibited by these scientists does not remove God totally from the picture; it is rather a commitment "to understand the nature of the matter, forces, and laws that God had made."21

The next centuries however have witnessed a significant turn towards the practice of science that becomes increasingly disassociated with God. For instance, the view that God is directly acting in the world through the laws of nature has become reduced to divine commands as stated in the Scriptures. By consequence, these laws were now seen as the key mediators of human beings to nature, while God becomes relegated to the side. As illustration for this change, Newton saw God as actively mediating in the world but the generation of Newtonians after him already abandoned that idea. ${ }^{22}$ The separation of nature from God eventually led to deism by the eighteenth century. Deism is the idea that God created the world but left the world to work and operate on its own without God's active involvement in it. According to this view, there is no such thing as a special divine revelation since that would entail that God can actually intervene in the world, an idea that is already taken as "psychologically jarring to the majority of theists [at that time]." ${ }^{, 23}$ It is apparent at this point that pure naturalism and non-supernaturalism, has succeeded to become the rule of the day. While many scientists remained believers in God, they saw God only as a First Cause, the Author of nature's laws but other than that, God has no scientific role to play. God was no longer invoked as a direct cause of anything happening in the world. Moreover, the only thing stopping these scientists from being metaphysical naturalists was that they still see God as the only explanation for the origin of the world and nature's laws but for the most part, God no longer explained anything within the created realm.

Biologists are the only exception to this growing trend. With the influence of William Paley (1743 - 1805), God is alive and actively involved in biology. Paley is of course the name that comes up if one is looking for a scholar who adopts the same religious outlook as Newton and applies it to biology. The publication of Paley's book entitled Natural Theology

\footnotetext{
${ }^{18}$ Robert C. Bishop, "God and Methodological Naturalism in the Scientific Revolution and Beyond," 13.

${ }^{19}$ Ibid., 12.

${ }^{20}$ Robert C. Bishop, "God and Methodological Naturalism in the Scientific Revolution and Beyond," 13.

${ }^{21}$ Ibid., 13.

${ }^{22}$ Margaret Jacob, "Christianity and the Newtonian Worldview," in God and Nature: Historical Essays on the Encounter between Christianity and Science, ed David C. Lindberg and Ronald N. Numbers (Berkeley: University of California Press, 1986), 246-249.

${ }^{23}$ Robert C. Bishop, "God and Methodological Naturalism in the Scientific Revolution and Beyond," 16.
} 
in 1802 immediately became a standard biology textbook at the time. This is a book that is rich in empirical observations, advancing one long argument to the effect that since many living things appear designed just like a watch is designed, it follows that they must have a designer, just as for every watch, there must be a watchmaker. Clearly, no MN is at work in Paley's case. In fact, his view goes beyond Newton's and is more in line with Aristotle's methodological theism. Paley explicitly declared that the designer of living things is the God of Christianity.

This was all about to change in the year 1859 when Charles Darwin (1812-1882) published The Origin of Species. During his studies, even Darwin himself found Paley's arguments convincing, which suggests the pervasive influence of Paley in the intellectual climate of Darwin's time. ${ }^{24}$ It was, however, during the celebrated Beagle voyage that Darwin found empirical evidence upon which he will later formulate what is now known as the theory of evolution. While Paley's theory merely inferred the necessity of a designer based on the contrivances of living things in nature, Darwin's theory provided a mechanism called natural selection to explain nature's organisms without any resort to an invisible designer. Later evolutionists have included random genetic mutation as another mechanism of evolution. In any case, Darwin replaced the seat that is once occupied by God with blind, unthinking nature. There are many things that make Darwin's theory controversial but in the context of our discussion, Darwin's theory represents a sudden break from the pattern of science that has relied in many ways to supernatural explanations.

Taken at face value, it would seem that Darwin is a full-fledged methodological naturalist: he provided a purely natural explanation to the origin of living things, his theory overturned an influential theory that relies on the supernatural and by consequence he would seem to have practiced science as if the supernatural does not exist or is at least scientifically unnecessary. Darwin may very well have been a methodological naturalist but to claim that the idea of God has nothing whatsoever to do with how he came up with his theory is flatly wrong. Darwin's theory is a product of a theistically inspired theory even if his theory emerged as a negative reaction to it. In other words, Paley's idea of design provided an essential background from which Darwin's theory was eventually constructed. Also, there are many early evolutionists and even Darwin himself who did not see anything in evolution that would count as evidence against God or the supernatural. ${ }^{25}$

But since evolutionary theory replaces a God-based theory, it is not difficult to utilize it to further a fully secular worldview. Thus, it is not uncommon to see thinkers and scientists who see evolution as something that can prove religion false. One example is Daniel Dennett, a contemporary philosopher who specializes in the philosophical implications of NeoDarwinism. He contends that evolution is like a universal acid that eats away at everything religion has supposedly provided. ${ }^{26}$ For Dennett and expectedly many others, Darwin's theory "is not just a wonderful scientific idea. It is a dangerous idea." 27 As a metaphysical worldview, "the idea of evolution by natural selection unifies the realm of life, meaning, and

\footnotetext{
${ }^{24}$ Allene Phy-Olsen, Evolution, Creationism, and Intelligent Design (Santa Barbara: Greenwood, 2010), 22.

${ }^{25}$ Alister McGrath, "The Ideological Uses of Evolutionary Biology in Recent Atheist Apologetics," in Biology and Ideology from Descartes to Dawkins, ed. Denis R. Alexander and Ronald L. Numbers (Chicago: The University of Chicago Press, 2010), 329-330.

${ }^{26}$ Daniel Dennett, Darwin's Dangerous Idea: Evolution and the Meanings of Life (New York: Touchstone, 1995), 61-84

${ }^{27}$ Ibid., 21.
} 
purpose with the realm of space and time, cause and effect, mechanism and physical law." 28 In a nutshell, Darwin's theory dismissed the long-held idea of nature's conscious designer, i.e., God, to be replaced by blind unconscious Mother Nature. The supposed atheistic implications of evolutionary theory are in large measure the reason why the theory is often made to appear as a contrary position with the doctrine of creation. ${ }^{29}$

Also, there is the well-known science popularizer Richard Dawkins, who is a distinguished biologist but also one of the faces of atheism in today's world. In his book The God Delusion, he considers God as a scientific hypothesis, something that can be proven empirically true or false. He advanced an argument to the effect that the God hypothesis is purportedly shown to be false. ${ }^{30}$ Regardless of the merit of Dawkins' atheistic argument, his approach is a new one: he believes he is using science to prove that there is no God. By this, it seems clear that Dawkins cannot be a methodological naturalist. For various reasons, supernatural entities such as God are according to MN not amenable to scientific study. Dawkins seems to think that science must be methodologically open to the possibility of either proving or refuting God. Dawkins however thinks that science has already proven the non-existence of the supernatural. Aside from Dawkins, there are also philosophers who hold this view. ${ }^{31}$

It is no surprise that Richard Dawkins would call evolution as the blind watchmaker, alluding to Paley's famous watchmaker analogy, to point out that evolutionary theory does not need a mindful designer such as the one propounded by Paley in order to explain nature's products and processes. ${ }^{32}$ If the theory of evolution is true as many scientists have claimed, then it appears to make the idea of God superfluous at best, nonexistent at worst. After all, if everything found in nature has a sufficient natural explanation for its coming to be, then what major role is there left for God? Although there remain many scientific mysteries that are left unsolved (such as the origin of the first form of life itself), the power of evolutionary theory to provide a natural explanation to the varieties of life found in nature gives more plausibility to the hypothesis that natural and not supernatural explanations will someday suffice to remove the mystery that surrounds these presently unsolved scientific conundrums. As Dawkins famously remarked, "Darwin made it possible to be an intellectually fulfilled atheist. ${ }^{, 33}$ In a nutshell, this is what the history of science apparently shows: The Presocratic thinkers were clearly methodological naturalists but the coming of Aristotle illustrates an early scientist whose thinking is that of what I called methodological theism. The science of the medieval period is expected to be laden with religious influences, especially of Christianity but as we have seen in the case of Philoponus, it is possible to practice science with the assumption of MN even though the foundation of this practice is that of religion. In one sense then, Philoponus is a methodological naturalist. The influence of Christianity continues until early modern science, albeit not as direct and pervasive as the idea of theism in the case of Aristotle. Scientists such as Galileo and Kepler already see the cosmos as

\footnotetext{
28 Ibid.

${ }^{29}$ See the following: Olivier Rieppel, Evolutionary Theory and the Creation Controversy (New York: Springer, 2011); Mano Singham, God vs. Darwin: The War between Evolution and Creationism in the Classroom (Plymouth: Rowman \& Littlefield Education, 2009); Edward J. Larson, The Evolution-Creation Debate:

Historical Perspectives (London: The University of Georgia Press, 2007).

${ }^{30}$ Richard Dawkins, The God Delusion (Sydney: Bantam Press, 2006), 157-8.

${ }^{31}$ Jerry A. Coyne, Faith vs. Fact: Why Science and Religion Are Incompatible (New York: Penguin Publishing Group, 2015).

${ }^{32}$ Richard Dawkins, The Blind Watchmaker (New York: W. W. Norton \& Co., 1986).

${ }^{33}$ Ibid., 6.
} 
qualitatively different from God the creator which follows that it can be studied on its own without any resort to God. Nevertheless, God is still seen as the Creator and Author of nature's laws.

Eventually, it is apparent that the role of God within the explanatory picture decreases over time, from having an active and direct role within the supposed explanation of things and eventually to be regarded simply as a higher-order explanation of the origin of the cosmos and its laws. This decrease of God's influence in science culminated in the rise of deism in the $17^{\text {th }}$ and $18^{\text {th }}$ centuries. Paley's design argument in biology remained influential for years until Darwin replaced it with a theory that is naturalistic in its core. There are a few who saw evolution as providing a thoroughly naturalistic way to explain certain biological facts, but they also see the theory as silent on whether there is God or not. In recent years however, there have arisen intellectuals who saw evolution in particular and even science in general as something that can disprove the existence of God and everything supernatural. In other words for these thinkers, science and religion are fundamentally incompatible. But in order to adopt that stance, one already has to abandon MN.

\section{THE SCIENCE-STOPPER ARGUMENT}

It is common to hear that religion is a "science-stopper", and that supernatural ideas when allowed to interfere or enter the purview of science would stop scientists from advancing scientific inquiry. ${ }^{34}$ After all, saying 'God did it' is not much of an explanation, as one might say. As Gurol Irzik and Robert Nola remarked, "To give up methodological naturalism is to give up science." 35 Let us call this the science-stopper claim. By consequence, this claim entails that in order to continue doing science, every scientist must adopt MN and thus excludes any supernatural explanation in their study. The question to be asked is this: does the idea of the supernatural or even the idea of God something that cuts the momentum of science in discovering new things about the world? This is where we see that historically speaking, this is not the case; in fact, the opposite is true: the idea of God has played an indispensable role in the development of science. If there is one definite thing we can say about the idea of God, it is this: it is not a science-stopper; it is a science-starter! At some point, Irzik and Nola utilized the oft-cited incident of Newton invoking God to explain the instability of the planetary system. Of course, the ending of the story is the incident with Laplace in which he was questioned by Napoleon why there is no mention of God in his system and Laplace replied, "I have no need of that hypothesis." ${ }^{36}$ Does this incident prove that invoking God is inherently a science-stopper? Hardly.

Let us consider some details based on our previous discussion. If the idea of God is a science-stopper, then science would never have progressed since Aristotle, and we would still have the Aristotelian view of the world up to this day. But of course, we have already come a long way since and what is even more surprising is the fact that the eventual transition from Aristotelian science to modern science is predicated on a Christian view of the world: the distinction between the Creator and the created. One may speculate how modern science could have nevertheless took off without it being necessarily attached to Christianity but all

\footnotetext{
${ }^{34}$ Nidhal Guessoum, "Islam and Science," in The Customization of Science: The Impact of Religious and Political Worldviews on Contemporary Science, ed. Steve Fuller, Mikael Stenmark and Ulf Zackariasson (New York: Palgrave Macmillan, 2014), 18.

${ }^{35}$ Gurol Irzik and Robert Nola, "Worldviews and Their Relation to Science," in Science, Worldviews, and Education, ed. M. R. Matthews (Sydney: Springer, 2009), 93.

${ }^{36}$ Ibid., 91-92.
} 
of these are reduced to mere speculations that will never be proven. Actual history dictates that the beginning of modern science owed much of itself to Christianity, and everyone, whether religious people or atheists, simply need to acknowledge that. Again, what is needed to refute the sweeping claim of Irzik and Nola is just one example of an appeal to God in science that did not put scientific inquiry into a definite halt, and as our discussion of history has shown there are in fact various examples that such is the case.

It is noteworthy that when Irzik and Nola made their pronouncement, they admit that arguing for the science-stopper claim is something they cannot do in their paper. ${ }^{37}$ However, they suggest two things in that direction, which are these: first is to "ally itself with philosophical critiques of supernatural entities" and secondly, science "needs to add its own case for the non-explanatory nature of appeals to such entities beyond empirical investigation" 38 . Strikingly, to change the direction of the science-stopper argument towards those two suggestions entails abandoning the original argument. For it would mean that Irzik and Nola's claim that abandoning $\mathrm{MN}$ means abandoning science cannot be supported by historical facts at all. There is no other way to support that claim other than surveying the history of science and assess whether any appeal to God leads to the complete halt of scientific inquiry.

Consider their suggestion that science needs to go hand in hand with philosophical critiques of supernatural entities. Barring the fact that the suggestion seems to show Irzik and Nola's implicit bias against the supernatural, it is not clear how this provides a good justification for their science-stopper claim. If philosophical critiques here are understood to mean a priori or even a posteriori arguments against the supernatural, then this does not provide any reason to suppose that introducing the supernatural by its nature entails abandoning science. Even if one assumes that these philosophical arguments are rationally compelling (I do not), it still does not follow that introducing God in this context means abandoning science. With regard to their second suggestion, it remains unclear how the alleged non-explanatory nature of supernatural explanations serves to confirm that appealing to such explanations spells the abandonment of science.

In fact, as Peter Harrison argued in detail, there are two ways "in which theological considerations contributed positively to scientific investigation." 39 First, Harrison suggests the notion that theological ideas can serve as " $a$ heuristic which could facilitate new avenues of theorizing and investigation." ${ }^{40}$ He gave two historical examples with regard to theological heuristics: first heuristic is the idea of divine omnipotence. Harrison noted two ways in which this theological heuristic has been historically valuable in science. First is how the idea is used to condemn the proposition that "God could not move the heaven in a straight line, the reason being that He would then leave a vacuum." 41 As Harrison noted, the traditional idea of horror vacui, nature abhorring a vacuum, is attributed to Aristotle. ${ }^{42}$ But the idea of God's omnipotence in this case enabled scholastic thinkers to think outside the Aristotelian framework and entertain hypothesis that are outside this prevailing paradigm.

\footnotetext{
${ }^{37}$ Gurol Irzik and Robert Nola, "Worldviews and Their Relation to Science," 93.

38 Ibid.

${ }^{39}$ Peter Harrison, "Naturalism and the Success of Science," Religious Studies 56, no. 2 (2018), 8.

${ }^{40}$ Ibid. Emphasis in the original.

${ }^{41}$ Edward Grant, A Source Book in Medieval Science (Cambridge: Cambridge University Press, 1974), 48;

Quoted in Peter Harrison, "Naturalism and the Success of Science," 9.

${ }^{42}$ Peter Harrison, "Naturalism and the Success of Science," 9.
} 
Second example is how the idea of omnipotence has given rise to what is now called the problem of theory being underdetermined by data. Del Ratzsch describes this problem succinctly: "Empirical data underdetermine scientific theories in that for any body of empirical data, no matter how large or complete, there are always in principle unlimitedly many theoretical interpretations consistent with those data." 43 Now, how did the idea of God's omnipotence connect with this problem? Harrison notes that Aquinas' commentary on Aristotle already expressed this problem in a way that was never anticipated before. ${ }^{44}$ Aquinas notes that it is possible for an empirically adequate, i.e., it fits with the empirical data, hypothesis to be false, "because the astronomical phenomena can perhaps be saved in some other way not yet understood by men." Aquinas entertained the possibility of other unknown theories explaining astronomical phenomena because he is rooted in the framework that God, being omnipotent, could have arranged the cosmos in any number of ways and some of these arrangements may have been in Aquinas' time still unknown to men. This clearly illustrates that the idea of divine omnipotence can serve as a valuable heuristic in scientific thinking.

Another theological heuristic that Harrison suggested is the idea of design. He gave the example of William Harvey's discovery of the circulation of blood in which "[f]or Harvey, the assumption of divine design provided a true insight into how blood circulated through the human body." 45 Another example, which has already been noted above, is the case of William Paley and how his idea of design in nature provided an impetus for Darwin to formulate his theory of evolution.

Given all these examples mentioned, it is clear that Irzik and Nola's assumption about the supposed non-explanatory nature of supernatural explanation is flawed. Rather, there are actual cases of supernatural explanations that are not empty, as in Paley's case, even if they may have turned out to be false. Alternatively, a proponent of MN may concede my point about the science-stopper argument being an historically inaccurate argument but may still claim that appeal to supernatural explanations has slowed down the pace by which modern science should have progressed. This is a stronger argument if only for the fact that, unlike the science-stopper argument, this is more in tune with the historical facts. Again, the examples that immediately come to mind are the case of Newton and Paley that appeared to have hampered the speed by which scientific discoveries would have been made. Perhaps if science would have realized the necessity of $\mathrm{MN}$ earlier in history-the necessity of excluding the supernatural from scientific investigation - the progress of science would have been faster. But in retrospect, since we are now aware of how supernatural appeals in science contributed to the slow pace of scientific progress, this provides a good reason to adopt MN and precludes any kind of supernatural appeals in science.

Does this argument work? While it seems predicated on some uncontentious historical facts, the force of the argument hinges on the idea of scientific progress. But what exactly is scientific progress, and what exactly is the standard of the proponent of the argument from scientific progress for saying that a particular incident does or does not exhibit the virtues of such progress. It seems that the proponent of this argument has to admit that the criteria for judging what scientific progress amounts to is whether it provided an adequate naturalistic

\footnotetext{
${ }^{43}$ Del Ratzsch. "Humanness in their Hearts: Where Science and Religion Fuse," in The Believing Primate: Scientific, Philosophical, and Theological Reflections on the Origins of Religion, ed. Jeffrey Schloss and Michael J. Murray (Oxford: Oxford University Press, 2009), 216.

${ }^{44}$ Peter Harrison, "Naturalism and the Success of Science," 9.

${ }^{45}$ Peter Harrison, "Naturalism and the Success of Science," 10.
} 
explanation to the phenomenon in question. Supernatural explanation is seen only as an impediment to the further presumed discovery that a naturalistic explanation will be forthcoming. This seems clearly the reason why the examples of Newton and Paley are seen as spectacular failures in behalf of supernatural appeals. For they illustrated that the speed of discovering the right theory of planetary motion or the theory of evolution would have likely been faster if scientists have learned to exclude any form of supernatural appeal in their scientific analysis.

However, one major problem for this argument is that it totally begs the question in favor of MN. The idea of God would only impede scientific progress if it is assumed beforehand that God can never serve as an explanation in science and that every possible scientific explanation will turn out to be naturalistic. But if scientific progress is measured according to how the totality of scientific theories is heading towards a completely naturalistic explanation of reality, then this means that any naturalistic explanation will appear as a significant contribution to the progress of science. On the contrary, a theistic explanation-however fitting, empirically adequate or even true - can never contribute to this progress.

This is where we can now see how the argument is entirely circular: the proponent of the argument claims that adopting $\mathrm{MN}$ would accelerate the progress of science. But he defined scientific progress to mean our ever-expanding knowledge with regard solely to the naturalistic explanations of any given phenomenon. If this is the case, theistic explanation has been defined away from ever contributing to scientific progress. But then, aside from this naturalistic view of scientific progress, the proponent of the argument has not provided any reason to suppose that progress in science must comprise only of naturalistic explanations. There is no reason to think that theistic explanations are in principle impediments to scientific progress unless one thinks that scientific progress excludes the possibility of any theistic explanation. In other words, the argument commits the fallacy of begging the question.

\section{THE GOD-OF-THE-GAPS ARGUMENT}

It is clear that the history of science moves from a starting-point of heavy religious commitments towards science that is now generally free from supernatural explanations. Things that were once attributed to God (motion, gravity) now do have perfectly natural explanations. Important details aside, there is a clear trajectory in science that moves towards a God-free scientific practice. Scientists now seem to have no need of the God hypothesis, echoing what Laplace supposedly said a long time ago. This is the well-known God-of-thegaps argument, the notion that the idea of God is simply to fill an explanatory gap that the current science has not presently explained. But as our discussion of the history of science shows, some of these gaps that God once explained have been adequately explicated through purely natural processes. The argument is then extended to imply that anything that is presently attributed to God or is best explained by God (e.g., fine-tuning in physics and cosmology, the fact of consciousness) can be expected to have a purely natural explanation in the future. Basing on science's history, this argument is extended to show that science, or at least methodologically naturalistic science, can in principle fill all the gaps that God presently occupies.

While the God-of-the-gaps argument may be persuasive for other purposes, it is actually detrimental to the cause of MN. If God as a scientific explanation has been shown to be false through empirical methods, this means that $\mathrm{MN}$ is not at work since if it is, God as an idea cannot be part of the discussion. Indeed, how can a scientist test the supernatural if by 
her own methodology, she assumes that there is none? For clarity, one may look at the inference to God (as in the case of Aristotle and Newton) as a scientific hypothesis that can be empirically verified or refuted. And since history has shown its refutation in some cases, i.e., replacement by a perfectly natural explanation that makes the idea of God empirically superfluous, it follows that the particular usage of this idea is testable and falsifiable. As Karl Popper famously argued, if an idea can be tested and falsified, it must count as a scientific hypothesis. ${ }^{46}$

Consider for instance scientific creationism, the movement that attempted to prove a literal interpretation of the Bible through scientific means. One prominent leader of this movement is George McCready Price who in his book The New Geology attempted to prove scientifically that there had been a flood as narrated in the book of Genesis. Price also believed that the earth is young, around 10,000 years old, based on the calculations of genealogy in Genesis and the literal interpretation that the world is created by God in only six days. For Price, "The Bible was the touchstone against which all knowledge must be tested." ${ }^{\text {A7 }}$ At first, it is easy to dismiss scientific creationism as non-scientific or a form of pseudo-science. Scientific creationism, the critics might say, is not science; it is 'religion masquerading as science'. ${ }^{48}$ The proponents of this idea like Price are regarded as pseudointellectuals motivated by religious motivations without serious regard for evidence, openmindedness, and honest inquiry. If the only legitimate standard for what would ultimately be true (even scientifically) is the Bible interpreted literally, this would indeed throw doubt to the honesty and open-mindedness of scientific creationists like Price. If the main assumption of scientific creationists is that a fundamentalist reading of the Bible is true and that it is the evidence that must ultimately fit that assumption, then it is legitimate to brand this way of thinking as thoroughly unscientific. Scientists must follow the evidence wherever it leads even if the direction to which it moves is one that may be in apparent conflict with one's religious assumptions. Galileo would never have confirmed the heliocentric theory if he resigned himself to accepting the geocentric view merely because the latter agrees with the dominant religious paradigm. Rather, Galileo opposed the reigning paradigm and allowed himself to be censored by religious authorities because evidence is accumulating, much of it he himself discovered, that the heliocentric view is true. ${ }^{49}$ Indeed, scientists must possess certain intellectual virtues in order to do proper science, and scientific creationists seem to lack many of them.

But suppose that scientific creationism is transformed into a way of doing science that takes the Bible not as an infallible document in all matters, scientific or otherwise, but simply an historical document whose claims are taken as scientific hypothesis that can be empirically verified or refuted. In this scenario, does scientific creationism count as legitimately scientific? It would seem so; after all, how is scientific creationism any different from doing science that attempts to test some hypothesis whose origins may be as varied as dreams, sudden burst of insight or an imaginative thought-experiment? To understand the point better, we need to distinguish between the context of discovery from the context of

\footnotetext{
${ }^{46}$ See Karl Popper, The Logic of Scientific Discovery (London: Routledge, 1992).

${ }^{47}$ Allene Phy-Olsen, Evolution, Creationism, and Intelligent Design, 60.

${ }^{48}$ This phrase is adopted from William Dembski, The Design Revolution: Answering the Toughest Questions about Intelligent Design (Downers Grove: InterVarsity Press, 2004), 20. Dembski is however giving a common description of Intelligent Design Theory, not scientific creationism.

${ }^{49}$ Richard J. Blackwell, "Galileo Galilei," in The History of Science and Religion in the Western Tradition, ed. Gary B. Ferngren (New York: Garland Publishing, Inc., 2000), 98-103.
} 
justification. ${ }^{50}$ The context of discovery refers to the manner by which a scientific theory is discovered while the context of justification refers to the arguments and set of evidence by which the scientific theory is justified. The former does not in any way undermine the latter; what is important for any scientific hypothesis is to be tested in fire and be confirmed by evidence. As has been pointed out by Angus Menuge and William Sweet, if the main complaint of a scientific hypothesis is its mere origin, this is reduced to the genetic fallacy. ${ }^{51}$ Karl Popper, a prominent philosopher of science, encouraged scientists to utilize different sources of inspiration when formulating their theory. For him, no source is illegitimate since "the causal origins of a hypothesis were irrelevant to its status within science."

In fact, it might appear that scientists who base their practice of science in certain religious commitments are assuming the conclusion of what needs to be proven whereas religiously neutral scientists are seen as observing data first before drawing any conclusion, thus making the latter appear more objective. But are religiously committed scientists really biased? There seems to be nothing wrong with making a claim based on certain religious commitments as long as such claim goes through the standard tests of science: experimentation, repeated and rigorous observations, replications and others. Such claims, even if religiously motivated, are nothing but scientific hypotheses that need to be empirically verified to be scientifically legitimate. It is however a different story when the evidence is manipulated to fit one's claim, but this problem afflicts not only religious scientists, but scientists of all stripes.

In any case, the God-of-the-gaps argument that relies on the history of science to substantiate MN seems bound to fail. One cannot claim that the history of science has debunked the idea of God and still hold that $\mathrm{MN}$ is a valid way of doing science. But how about the case of Richard Dawkins who think that science has actually disproven the existence of God? This seems also bound to fail. Take for instance the idea of God as the most perfect being, an idea that has most fully developed in the Judeo-Christian tradition. ${ }^{53}$ Can science disprove God understood in this way? Since God is perfect, God cannot be material since material things are by their nature corruptible and corruptibility is an imperfection. But if God is by nature immaterial, then it is not clear how science will disprove God. What kind of lab experiment would have to be designed to prove that God does not exist?

There is, however, a plausible way to see the history of science as supporting MN. We see that one major reason that science did not fully blossom in ancient Greece is because of the ancient Greek's way of looking at celestial bodies; they see it as qualitatively similar to the divine and thus they presume that they can discover facts about celestial bodies just by ruminating about them. Early modern scientists, spurred by the Christian view that the Creator and the created are fundamentally different, found it necessary to observe and explore the world, rather than just try to discover a priori facts about it. MN respects this essential difference by putting a clear line between the created world and God. By their

\footnotetext{
${ }^{50}$ James Ladyman, Understanding Philosophy of Science (New York: Routledge, 2002), 90.

${ }^{51}$ Angus Menuge, "Who's Afraid of ID?" in Debating Design: From Darwin to DNA, ed. William Dembski and Michael Ruse (Cambridge: Cambridge University Press, 2006), 36; William Sweet. "Science and Religious Belief: Some Conceptual Issues," in Religion and the Challenges of Science, ed. William Sweet and Richard Feist (Hampshire: Ashgate, 2007), 220.

52 James Ladyman, Understanding Philosophy of Science, 75.

${ }^{53}$ Mark Owen Webb, "Perfect Being Theology," in Blackwell Companion to Philosophy of Religion, $2^{\text {nd }}$ ed., ed. Charles Taliaferro, Paul Draper, and Philip L. Quinn (Oxford: Blackwell Publishing Ltd., 2010), 227.
} 
nature of being created, our universe and everything in it are therefore capable of being studied scientifically; God, however, is not. If one wants to know about God, special divine revelation may be needed. Thus, Galileo found it necessary to introduce his two books metaphor which in a way acknowledges that different things are needed to understand the book of nature (natural world) and the book of revelation (Scriptures). To apply MN then need not mean that scientists support metaphysical naturalism; it may be, as in Philoponus' and Galileo's case, to recognize that science is capable of studying only the created world but not God who created it. This is not to limit how God may interact with the world but only the extent to which science can be appropriately applied. $\mathrm{MN}$ is therefore a philosophical presupposition that can be supported historically but it should not be separated from the theistic context from which it emerged, something which is directly contradictory to the idea that the right way to do science is to assume atheism.

The argument above appears to put $\mathrm{MN}$ in a privileged position: in the middle of two completely different realms where its role is to separate the two by relegating the created realm within the control of humans to study while elevating God to the status in which science is incapable of traversing. There would be no problem if these two realms are inherently so separate from one another that no possible interaction is possible. But this is generally not the case. Major religious traditions, such as Christianity, take it as their basic tenet that God is a personal God, a conscious agent who is constantly active in history. So if this is true, then MN cannot be an adequate methodology since the option of explanations is rigged in favor of a natural one even if a natural explanation is ultimately incorrect (because presumably, the explanation is a supernatural one). If God is believed to play an active role in human history, for instance by performing miracles, then MN by consequence assumes that there can be no miracles in the sense that these allegedly miraculous occurrences can have no perfectly natural, although currently unknown, explanations. In fact, the philosopher of science Michael Ruse's definition of MN is particularly relevant: "The assumption that in doing science there are no God-directed supernatural causes like miracles." "54 It would seem then that a methodological naturalist is compelled to affirm that an alleged miracle claim will ultimately have a purely natural explanation. By consequence, a theistic scientist cannot uphold MN since he is committed to the reality of miracles, events that are best explained as a special action of God in the world.

\section{CONCLUSION}

In any case, the complexity of the history of science and how MN arose within it illustrates the problems of characterizing the whole history or even the majority of science as something that is necessarily intertwined with MN. We have seen that there have been many pivotal thinkers and scientists throughout history whose religious views are something that inspired the trajectory of their scientific thinking. We also see that many presuppositions in science now, such as the intelligibility and regularity of nature, have their roots within Christianity. Although counter-intuitive for many modern minds, this idea is not surprising especially when seen in the context of how early modern science emerged from the dominance of the Aristotelian worldview. If MN entails that no supernatural idea in whatever context should be taken into account when practicing science, much of ancient and early modern science would not subscribe to it. It is therefore a mistake to assume that $\mathrm{MN}$ has always been an inherent component of science throughout history.

\footnotetext{
${ }^{54}$ Michael Ruse, “Atheism, Naturalism and Science: Three in One?”, 229.
} 


\section{BIBLIOGRAPHY:}

[1] Aristotle. "Metaphysics." In The Complete Works of Aristotle, edited by Jonathan Barnes. Princeton: Princeton University Press, 1984, pp. 3343-3716.

[2] Axe, Douglas. Undeniable: How Biology Confirms Our Intuition that Life is Designed. New York: HarperOne, 2016.

[3] Behe, Michael. Darwin's Black Box: The Biochemical Challenge to Evolution. New York: Free Press, 1996

[4] Bishop, Robert C. "What Is This Naturalism Stuff All About?" Journal of Theoretical and Philosophical Psychology 29, no. 2 (2009), pp. 108-113.

[5] Blackwell, Richard J. "Galileo Galilei." In The History of Science and Religion in the Western Tradition, edited by Gary B. Ferngren. New York: Garland Publishing, Inc., 2000, pp. 98-103.

[6] Clarke, Samuel. The Works of Samuel Clarke, D.D., first volume. London: 1738.

[7] Coyne, Jerry A. Faith vs. Fact: Why Science and Religion Are Incompatible. New York: Penguin Publishing Group, 2015.

[8] Dawkins, Richard. The God Delusion. Sydney: Bantam Press, 2006.

[9] Dembski, William. The Design Revolution: Answering the Toughest Questions about Intelligent Design. Downers Grove: InterVarsity Press, 2004.

[10] Dembski, William. The Design Inference: Eliminating Chance through Small Probabilities. New York: Cambridge University Press, 1998.

[11] Dennett, Daniel. Darwin's Dangerous Idea: Evolution and the Meanings of Life. New York: Touchstone, 1995.

[12] Grant, Edward. A Source Book in Medieval Science. Cambridge: Cambridge University Press, 1974.

[13] Guessoum, Nidhal. "Islam and Science." In The Customization of Science: The Impact of Religious and Political Worldviews on Contemporary Science, edited by Steve Fuller, Mikael Stenmark and Ulf Zackariasson. New York: Palgrave Macmillan, 2014, pp. 21-36.

[14] Harrison, Peter. "Naturalism and the Success of Science." Religious Studies 56, no. 2 (2018), pp. 1-18.

[15] Irzik, Gurol and Robert Nola. "Worldviews and Their Relation to Science." In Science, Worldviews, and Education, ed. M. R. Matthews. Sydney: Springer, 2009, pp. 81-97.

[16] Jacob, Margaret. "Christianity and the Newtonian Worldview." In God and Nature: Historical Essays on the Encounter between Christianity and Science, eds. David C. Lindberg and Ronald N. Numbers. Berkeley: University of California Press, 1986, pp. 238-255.

[17] Kirk, G. S. \& Raven, J. E. The Presocratic Philosophers. Cambridge: Cambridge University Press, 1957.

[18] Ladyman, James. Understanding Philosophy of Science. New York: Routledge, 2002.

[19] Larson, Edward. The Creation-Evolution Debate: Historical Perspectives. London: The University of Georgia Press, 2007.

[20] McGrath, Alister. "The Ideological Uses of Evolutionary Biology in Recent Atheist Apologetics." In Biology and Ideology from Descartes to Dawkins, eds. Denis R. Alexander and Ronald N. Numbers. Chicago: The University of Chicago Press, 2010, pp. 329-351.

[21] Menuge, Angus. "Who's Afraid of ID?" In Debating Design: From Darwin to DNA, eds. William Dembski and Michael Ruse. Cambridge: Cambridge University Press, 2006, pp. 32-51.

[22] Meyer, Stephen C.. Darwin's Doubt: The Explosive Origin of Animal Life and the Case for Intelligent Design. San Francisco: HarperOne, 2013.

[23] Meyer, Stephen C. Signature in the Cell: DNA and the Evidence for Intelligent Design. New York: HarperCollins Publishers, Inc., 2009.

[24] Newton, Isaac. Isaac Newton's Papers and Letters on Natural Philosophy, edited by I. Bernard Cohen. Cambridge: Harvard University Press, 1958.

[25] Numbers, Ronald L. "Science without God: Natural Laws and Christian Beliefs," in When Science and Christianity Meet, eds. David C. Lindberg and Ronald L. Numbers. Chicago: The University of Chicago Press, 2003, 265-285.

[26] Pennock, Robert. Tower of Babel: The Evidence Against the New Creationism. Cambridge: The MIT Press, 1999.

[27] Phy-Olsen, Allene. Evolution, Creationism, and Intelligent Design. Oxford: Greenwood, 2010.

[28] Popper, Karl. The Logic of Scientific Discovery. London: Routledge, 1992. 
[29] Ratzsch, Del. "The Nature of Science." In Science and Religion in Dialogue, edited by Melville Y. Stewart. Chichester: Wiley-Blackwell, 2010.

[30] Ratzsch, Del. "Humanness in their Hearts: Where Science and Religion Fuse." In The Believing Primate: Scientific, Philosophical, and Theological Reflections on the Origins of Religion, eds. Jeffrey Schloss and Michael J. Murray. Oxford: Oxford University Press, 2009, 215-245.

[31] Rieppel, Olivier. Evolutionary Theory and the Creation Controversy. New York: Springer, 2011.

[31] Ruse, Michael. "Atheism, Naturalism and Science: Three in One?" In The Cambridge Companion to Science and Religion, ed. Peter Harrison. Cambridge: Cambridge University Press, 2010, pp. 229-243.

[32] Singham, Mano. God vs. Darwin: The War between Evolution and Creationism in the Classroom. Plymouth: Rowman \& Littlefield Education, 2009.

[33] Sweet, William. "Science and Religious Belief: Some Conceptual Issues." In Religion and the Challenges of Science, edited by William Sweet and Richard Feist. Hampshire: Ashgate, 2007, pp. 217-232.

[34] Webb, Mark Owen. "Perfect Being Theology." In Blackwell Companion to Philosophy of Religion, $2^{\text {nd }}$ ed., eds. Charles Taliaferro, Paul Draper, and Philip L. Quinn. Oxford: Blackwell, 2010, pp. 227-234

[35] Wells, Jonathan. The Myth of Junk DNA. Seattle: Discovery Institute Press, 2011. 